\title{
Inhibition of Creatine Kinase Activity by Cystine in the Kidney of Young Rats
}

\author{
VIRGINIA CIELO RECH, GENARO AZAMBUJA ATHAYDES, LUCIANE ROSA FEKSA, \\ PAULA KARINE BARCELOS DORNELLES, VALNES RODRIGUES-JUNIOR, CARLOS SEVERO DUTRA-FILHO, \\ ANGELA TEREZINHA DE SOUZA WYSE, MOACIR WAJNER, AND CLOVIS M. D. WANNMACHER \\ Departamento de Bioquímica, Instituto de Ciências Básicas da Saúde, Universidade Federal do Rio Grande do Sul, Porto Alegre, \\ Rua Ramiro Barcelos 2600, CEP 90.035-003, RS, Brazil
}

\begin{abstract}
Nephropathic cystinosis is a lethal genetic disease caused by a lysosomal transport disorder leading to intralysosomal cystine accumulation in all tissues. Cystinosis is the most common inherited cause of Fanconi syndrome, but the mechanisms by which cystine causes tissue damage are not fully understood. Thiolcontaining enzymes are critical for renal energy metabolism and may be altered by disulfides like cystine. Therefore, in the present study our main objective was to investigate the in vivo and in vitro effects of cystine on creatine kinase, which contains critical thiol groups in its structure, in the kidney of young Wistar rats. We observed that cystine inhibited in vivo and in vitro the enzyme activity and that this inhibition was prevented by cysteamine and glutathione. The results suggest oxidation of essential sulfhydryl groups necessary for creatine kinase function by cystine. Considering that creatine kinase and other thiol-containing enzymes are crucial for renal energy metabolism, and programmed cell death occurs in situations of energy deficiency, the enzyme inhibition caused by cystine released from lysosomes might be a mechanism of tissue damage in patients with cystinosis. (Pediatr Res 60: 190-195, 2006)
\end{abstract}

$\mathrm{N}^{\mathrm{e}}$ phropathic cystinosis is an autosomal recessive disease characterized by a defect in the transport of cystine out of lysosomes, leading to intralysosomal accumulation of cystine in most body tissues (1). It is caused by lack of expression of the gene encoding cystinosin, the lysosomal membrane cystine transporter (2). Cystine accumulation leads to renal failure and other systemic complications in nontreated cystinotic children (3). CSH treatment, when initiated in the first $2 \mathrm{y}$ of age, reduces the intracellular concentrations of cystine, delaying the evolution toward end stage renal disease (4). The first clinical symptoms occurring in early childhood are severe electrolyte disturbances, urinary loss of solutes, and failure to thrive, and are thought to be due to the Fanconi syndrome (5). Histopathological studies showed evidence of a temporal relationship between cellular cystine accumulation, the devel-

Received October 25, 2005; accepted March 15, 2006

Correspondence: Clovis M.D. Wannmacher, M.D., Departamento de Bioquímica, Instituto de Ciências Básicas da Saúde, UFRGS, Rua Ramiro Barcelos 2600, CEP 90.035-003, Porto Alegre, RS, Brazil; e-mail: clovisdw@ufrgs.br

Supported, in part, by grants from Conselho Nacional de Desenvolvimento Científico e tecnológico (CNPq-Brazil), Fundação de Amparo à Pesquisa do Rio Grande do Sul (FAPERGS, RS-Brazil) and Programa de Núcleos de Excelência-Financiadora de Estudos e Projetos (PRONEX II, FINEP-CNPq-Brazil).

DOI: $10.1203 / 01 . p d r .0000227442 .78881 .47$ opment of the characteristic "swan neck" lesion of the proximal tubule and the Fanconi syndrome (6). Lysosomal localization of cystinosin in human proximal tubular cell supported its defect in cystinosis (7).

It is well known that some enzyme activities may be altered by thiol/disulfide exchange between protein sulfhydryl groups and biologically occurring disulfides (8). CK (EC 2.7.3.2) is a thiol-containing enzyme that catalyzes the reversible transfer of the phosphoryl group from phosphocreatine to ADP, regenerating ATP. This enzyme exerts a key role in cellular energy metabolism of tissues with high energy requirements (9). There are distinct CK isoenzymes, which are compartmentalized specifically in places where energy is released (mitochondria) or used (cytosol). The kidney contains BB-CK (cytosolic isoform) and ubiquitous Mi-CK (mitochondrial isoform). These isoforms are present in the renal cortex and outer medulla, possibly supplying energy necessary for sodium transport in the nephron (10). Sodium-dependent transporters were shown to be inhibited in immortalized human kidney epithelial cells loaded with cystine dimethyl ester (11), suggesting a possible involvement of CK activity. One of the factors that enable cells to undergo apoptosis, or other form of programmed cell death, is an alteration of mitochondrial permeability with consequent reduction of ATP supply (12). In this context, we have recently reported that cystine inhibits CK activity in vitro in the brain of young rats (13).

On the other hand, considering that cystine is a disulfide, it is feasible that it may act on intracellular thiol-enzymes, like $\mathrm{CK}$, modifying cell function and contributing to cell death. Therefore, in the present study we investigated the in vivo and in vitro effects of cystine on CK activity in mitochondrial and cytosolic fractions of rat kidney. We also investigated the effects of cysteamine and reduced GSH, a thiol-containing peptide, on the inhibition caused by cystine on the enzyme activity.

\section{METHODS}

Animals and reagents. Sixty 21-d-old Wistar rats bred in the Department of Biochemistry, UFRGS, were used in the experiments. At this age, Wistar rat development is equivalent to the development of a 6-y-old child. The

Abbreviations: CK, creatine kinase; CSH, cysteamine; Cys, cystine; GSH, reduced glutathione 
animals were kept with dams until they were killed. The dams had free access to water and to a standard commercial chow (Supra, Porto Alegre, RS, Brazil) containing $20.5 \%$ protein (predominantly soybean supplemented with methionine), $54 \%$ carbohydrate, $4.5 \%$ fiber, $4 \%$ lipids, $7 \%$ ash, and $10 \%$ moisture. Temperature was maintained at $24 \pm 1{ }^{\circ} \mathrm{C}$, with a $12-12 \mathrm{~h}$ light-dark cycle. The Principles of Laboratory Animal Care (National Institutes of Health publication 85-23, revised 1985) were followed in all the experiments, and the Ethics Committee for Animal Research of the Federal University of Rio Grande do Sul approved the experimental protocol. All chemicals were purchased from Sigma Chemical Co. (St. Louis, MO).

In vivo experiments. Twenty-four animals were randomly separated into four groups and received administration of $20 \mu \mathrm{L} / \mathrm{g}$ body weight of one of the following buffered solutions ( $\mathrm{pH}$ 7.4): $0.85 \mathrm{~g} \%$ saline (control group), $50 \mathrm{mM}$ cystine (Cys group), $13 \mathrm{mM}$ cysteamine (CSH group), or $50 \mathrm{mM}$ cystine + $13 \mathrm{mM}$ cysteamine (Cys + CSH group). Cysteamine was administered subcutaneously and saline or cystine was administered intraperitoneally. Cystine dose was chosen to achieve $0.5 \mathrm{mM}$ concentration in kidney tissue after $60 \mathrm{~min}$ (controls $<0.2 \mathrm{mM}$ ); cysteamine dose was similar to that used to treat patients affected by cystinosis (1). Rats were killed after $1 \mathrm{~h}$ and the kidneys removed for cystine and CK activity determination.

Preparation of renal tissue. Treated and nontreated animals were killed by decapitation, the kidneys were rapidly removed, decapsulated, washed, and homogenized with a Teflon-glass homogenizer in 5 vol of ice-cold SET buffer $(0.32 \mathrm{M}$ sucrose, $1 \mathrm{mM}$ EGTA, $10 \mathrm{mM}$ Tris- $\mathrm{HCl}), \mathrm{pH}$ 7.4. The homogenate was centrifuged at $800 \times g$ for $10 \mathrm{~min}$, the pellet was discarded and the supernatant was centrifuged at $10,000 \times g$ for $15 \mathrm{~min}$. The supernatant solution of the second centrifugation, containing the cytosol and other cellular components such as endoplasmic reticulum and lysosomes, was collected for determination of the cytosolic CK activity. The pellet, containing mitochondria, was washed twice with the same isotonic SET buffer, resuspended in 100

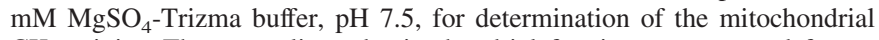
CK activity. The cytosolic and mitochondrial fractions were stored for no more than $1 \mathrm{wk}$ at $-70^{\circ} \mathrm{C}$ in case the enzymatic assay was not carried out immediately after the subcellular preparations. The mitochondrial fraction was frozen and thawed three times immediately before the assay to break mitochondrial membranes, facilitating the interaction between CK and the substrates.

Cystine determination. The cystine content in kidney tissue was measured according to Sullivan et al. (15) using cystine as the standard. Briefly, proteins were removed from kidney homogenate with 5\% TCA (trichloroacetic acid). Fifty microliters of the supernatant were mixed with $20 \mu \mathrm{L}$ of $1 \mathrm{mM}$ sodium cyanide to liberate cysteine from cystine. After $10 \mathrm{~min}, 10 \mu \mathrm{L}$ of $40 \mathrm{mM}$ sodium 1,2-naphtoquinone-4-sulfonate, $50 \mu \mathrm{L}$ of $0.8 \mathrm{M}$ sodium sulfite, and $10 \mu \mathrm{L}$ of $0.25 \mathrm{M}$ sodium hyposulfite were added. The absorbance was measured in a spectrophotometer at $530 \mathrm{~nm}$. The content of cysteine and other thiols was measured by the same method, using water instead of cyanide. The difference between the two measures was considered as cystine.

Creatine kinase activity assay. The reaction mixture contained the following final concentrations: $300 \mathrm{mM}$ Tris- $\mathrm{HCl}$ buffer, $\mathrm{pH}$ 7.5, $7 \mathrm{mM}$ phosphocreatine, $9 \mathrm{mM} \mathrm{MgSO}_{4}$, and approximately $1 \mu \mathrm{g}$ protein in a final volume of $0.13 \mathrm{~mL}$. After a variable time of preincubation at $37^{\circ} \mathrm{C}(0,30$, or $60 \mathrm{~min})$, the enzymatic reaction was started by the addition of $0.42 \mu \mathrm{mol}$ ADP. In the experiments performed to test the influence of GSH and CSH on the inhibition caused by cystine, $1 \mathrm{mM} \mathrm{GSH}$ or $2 \mathrm{mM} \mathrm{CSH}$ were added before (to evaluate prevention) or after (to evaluate reversion) preincubation of the enzymatic material (cytosolic or mitochondrial fraction) for 0,30 , and $60 \mathrm{~min}$ in the presence of cystine. The reaction was stopped after $10 \mathrm{~min}$ incubation by the addition of $1 \mu \mathrm{mol}$ p-hydroxymercuribenzoic acid. The reagent concentrations and the incubation time were chosen to assure linearity of the enzymatic reaction. Appropriate controls were carried out to discount chemical hydrolysis of phosphocreatine and the amount of creatine already present in the enzymatic material. The creatine formed by the enzymatic action was estimated according to the colorimetric method of Hughes (16). The color was developed by the addition of $0.1 \mathrm{~mL} 2 \% \quad \alpha$-naphthol and $0.1 \mathrm{~mL} 0.05 \%$ diacetyl in a final volume of $1 \mathrm{~mL}$ and read after $20 \mathrm{~min}$ at $540 \mathrm{~nm}$. None of the substances added to the assay medium interfered with the color development or spectrophotometric readings. Results were expressed as nmol of creatine formed per min per mg protein.

For the in vivo experiments, CK activity was measured in the absence and in the presence of $1 \mathrm{mM}$ reduced GSH, the most abundant thiol-containing peptide of the kidney, which achieves $5 \mathrm{mM}$ concentration in both mitochondria and cytosol of the renal tubular cells (17).

The in vitro experiments were performed in the following sequence:

1. Cystine was added to the incubation medium at $0.2,0.5$, and $1.0 \mathrm{mM}$ final concentrations without preincubation $(0 \mathrm{~min})$ or preincubated for 30 or $60 \mathrm{~min}$;
2. Cystine was added to the incubation medium at $0.5 \mathrm{mM}$ final concentration and preincubated for 0,30 , or $60 \mathrm{~min} ; 1 \mathrm{mM}$ reduced GSH was added before preincubation or after 30 or $60 \mathrm{~min}$ of preincubation;

3. Cystine was added to the incubation medium at $0.5 \mathrm{mM}$ final concentration and preincubated for 0,30 , and $60 \mathrm{~min} ; 2 \mathrm{mM}$ cysteamine was added before preincubation or after 30 or 60 min of preincubation;

4. Competition studies between cystine and the enzyme substrates phosphocreatine or ADP and the determination of the Michaelis-Menten constant $\left(K_{m}\right)$ was performed according to Lineweaver and Burk (18). In these experiments, phosphocreatine or ADP concentrations were chosen to assure linearity of creatine kinase activity and cystine inhibition. The values of the inhibition constant $\left(K_{i}\right)$ were determined according to Dixon and Webb (19).

Protein determination. The protein content was determined by the method of Lowry et al. (14) using BSA as the standard.

Statistical analysis. Data were analyzed by one-way ANOVA followed by the Tukey test when the $\mathrm{F}$ values were significant. Concentration or time dependent effects were analyzed by linear regression. All data were analyzed by the Statistical Package for the Social Sciences (SPSS; SPSS Inc., Chicago, IL) software using a personal computer.

\section{RESULTS}

First, the animals were subjected to administration of cystine, cysteamine, or cystine plus cysteamine. Creatine kinase activity was then measured in the presence and in the absence of GSH in the assay. When measured in the absence of GSH, cystine administration reduced $\mathrm{CK}$ activity in the mitochondrial $\left(\mathrm{F}_{3,16}=3.56, p<0.05\right)$ and cytosolic $\left(\mathrm{F}_{3,20}=7.91, p<\right.$ 0.001) fractions. Furthermore, cysteamine administration did not alter CK activity but prevented the enzymatic inhibition caused by cystine. When CK activity was measured in the presence of GSH, we did not observe differences between controls and the other groups in the mitochondrial $\left(\mathrm{F}_{3,16}=\right.$ $2.21, p>0.12)$ and cytosolic $\left(\mathrm{F}_{3,20}=1.64, p>0.21\right)$ fractions, indicating that the inhibition caused by cystine was reversible, possibly occurring through oxidation of the thiol groups of the enzyme (Table 1).

Next, cystine at $0.2,0.5$, and $1.0 \mathrm{mM}$ final concentrations was added to the incubation medium containing the cytosolic or the mitochondrial kidney fractions obtained from nontreated rats without preincubation, or preincubated for 30 and $60 \mathrm{~min}$. The linear regression showed that cystine significantly inhibited CK activity in the cytosolic fraction in all assays in a concentration-dependent way: $\mathrm{F}_{1,26}=36.84, \beta=-0.77, p$ $<0.0001$ (without preincubation); $\mathrm{F}_{1,26}=52.52, \beta=-0.82$, $p<0.0001$ (30 min of preincubation); $\mathrm{F}_{1,26}=23.63, \beta=$ $-0.69, p<0.0001$ (60 min of preincubation) (Fig. 1A). The same pattern of inhibition was observed for CK activity in the

Table 1. In vivo effect of cystine, cysteamine, and cystine plus cysteamine on creatine kinase activity in cytosolic and mitochondrial fractions in the kidney from young rats

\begin{tabular}{lcccc}
\hline & \multicolumn{4}{c}{ Group } \\
\cline { 2 - 5 } \multicolumn{1}{c}{ Cellular fraction } & Control & Cystine & Cysteamine & $\begin{array}{c}\text { Cystine }+ \\
\text { cysteamine }\end{array}$ \\
\hline Mitochondrial & $101 \pm 7$ & $84 \pm 9^{*}$ & $90 \pm 8$ & $91 \pm 10$ \\
Mitochondrial + GSH & $110 \pm 7$ & $108 \pm 11$ & $102 \pm 14$ & $92 \pm 9$ \\
Cytosolic & $121 \pm 7$ & $105 \pm 6 \dagger$ & $123 \pm 5$ & $118 \pm 9$ \\
Cytosolic + GSH & $116 \pm 8$ & $110 \pm 6$ & $123 \pm 17$ & $118 \pm 10$ \\
\hline
\end{tabular}

Creatine kinase activity is expressed as nmol creatine per minute per $\mathrm{mg}$ protein. Data are means $\pm \mathrm{SD}$ for $n=5-6$ independent experiments performed in triplicate.

$* p<0.05, \dagger p<0.01$ compared with control (Tukey test). 
mitochondrial fraction: $\mathrm{F}_{1,26}=125.81, \beta=-0.91, p<$ 0.0001 (without preincubation); $\mathrm{F}_{1,26}=32.67, \beta=-0.75, p$ $<0.0001$ (30 min of preincubation); $\mathrm{F}_{1,26}=16.46, \beta=$ $-0.62, p<0.001$ (60 min of preincubation) (Fig. $1 B$ ). The linear regression also showed that cystine inhibited $\mathrm{CK}$ activity at all tested concentrations in a time-dependent way in the cytosolic fraction $\left(\mathrm{F}_{1,19}=26.68, \beta=-0.76, p<0.001\right.$ (control); $\mathrm{F}_{1,19}=88.42, \beta=-0.91, p<0.0001(0.2 \mathrm{mM}$ cystine); $\mathrm{F}_{1,19}=38.55, \beta=-0.82, p<0.0001(0.5 \mathrm{mM}$ cystine); $\mathrm{F}_{1,19}=20.40, \beta=-0.72, p<0.001(1 \mathrm{mM}$ cystine). However, in the mitochondrial fraction, no timedependent inhibition was observed.

Considering that $\mathrm{CK}$ is a thiol-enzyme and cystine is a disulfide, we investigated the in vitro effects of GSH on the CK inhibitory effects of cystine. We first evaluated whether the inhibition caused by $0.5 \mathrm{mM}$ cystine on CK activity was preventable or reversible by adding $1 \mathrm{mM} \mathrm{GSH}$ in the cyto-
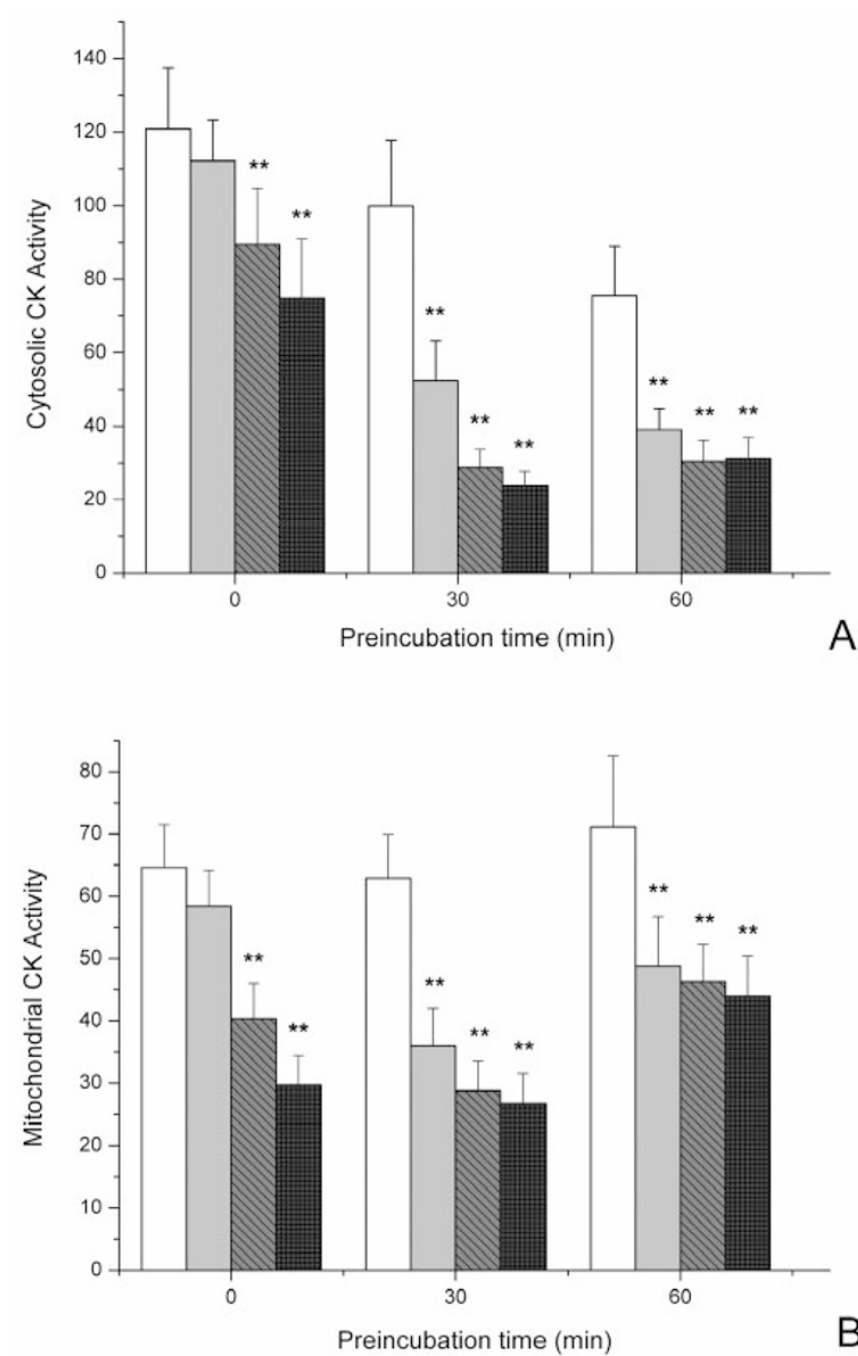

Figure 1. In vitro effects of cystine (Cys) for 0 (without preincubation) 30 , and $60 \mathrm{~min}$ of preincubation on creatine kinase activity in cytosolic $(A)$ and mitochondrial $(B)$ fractions in the kidney from young rats. Creatine kinase activity is expressed as nmol creatine per minute per mg protein. Data are means $\pm \mathrm{SD}$ for $n=6-8$ independent experiments performed in triplicate. ${ }^{*} p$ $<0.01 ; * * p<0.001$ compared with control (Tukey test). None (control, open bars); Cys $0.2 \mathrm{mM}$ (light gray bars); Cys $0.5 \mathrm{mM}$ (dark gray bars); Cys $1 \mathrm{mM}$ (black bars). solic and mitochondrial fractions, without preincubation or with preincubation of 30 or $60 \mathrm{~min}$. Our results showed that cystine inhibited the cytosolic CK activity, whereas GSH fully prevented this inhibition without preincubation: $\left(\mathrm{F}_{3,20}=\right.$ 11.21, $p<0.001)$ or with $30 \mathrm{~min}$ of preincubation $\left(\mathrm{F}_{5,42}=\right.$ 46.91, $p<0.001)$. However, reversion and prevention induced by GSH were only partial when the preparations were preincubated for $60 \min \left(\mathrm{F}_{5,42}=49.18, p<0.001\right)$. Cystine also inhibited the mitochondrial $\mathrm{CK}$ activity and GSH prevented this effect without preincubation $\left(\mathrm{F}_{3,28}=6.9, p<\right.$ 0.01 ), and by preincubating the mitochondrial fraction for 30 $\min \left(\mathrm{F}_{5,42}=33.11, p<0.001\right)$ or $60 \min \left(\mathrm{F}_{5,42}=6.34, p<\right.$ $0.001)$, but did not reverse the effect caused by cystine when preincubated for 30 or $60 \mathrm{~min}$ (Table 2).

Considering that cysteamine $(\mathrm{CSH})$ is a thiol-compound like GSH and has been used in the treatment of patients with cystinosis, we also investigated CSH effect on the inhibition of $\mathrm{CK}$ activity caused by cystine in the cytosolic and mitochondrial fractions, by adding $2.0 \mathrm{mM}$ cysteamine without preincubation or after 30 or 60 min of preincubation with $0.5 \mathrm{mM}$ cystine. Our results showed that $0.5 \mathrm{mM}$ cystine inhibited the cytosolic CK activity, whereas CSH fully prevented the inhibition occurring without preincubation $\left(\mathrm{F}_{3,20}=5.48, p<\right.$ 0.01 ), and partially prevented and reversed cystine-induced $\mathrm{CK}$ inhibition when preincubated for $30 \mathrm{~min}\left(\mathrm{~F}_{5,30}=138.51\right.$, $p<0.001)$ or for $\left.60 \min \left(\mathrm{F}_{5,30}\right)=89.47, p<0.001\right)$. Cystine also inhibited the mitochondrial $\mathrm{CK}$ activity, whereas $\mathrm{CSH}$ fully prevented this inhibition in the absence of preincubation $\left(\mathrm{F}_{3,28}=9.84, p<0.001\right)$ or when preincubated for $30 \mathrm{~min}$ $\left(\mathrm{F}_{5,42}=28.3, p<0.001\right)$ or for $60 \mathrm{~min}\left(\mathrm{~F}_{5,42}=9.55, p<\right.$ $0.001)$. CSH also fully reversed the $\mathrm{CK}$ inhibition caused by cystine when preincubated for $60 \mathrm{~min}$ and partially reversed this effect with $30 \mathrm{~min}$ of preincubation (Table 3 ).

In an attempt to better characterize the inhibition of $\mathrm{CK}$ activity caused by cystine, competition studies between cystine and the enzyme substrates ADP and phosphocreatine were performed in the absence of preincubation, according to the Lineweaver-Burk plot (not shown). The double-reciprocal plots showed that the inhibition caused by cystine on the cytosolic and mitochondrial CK activity was of the noncompetitive type for the two substrates, reinforcing the results obtained with GSH and cysteamine. The $K_{m}$ values for the cytosolic CK calculated from the Lineweaver-Burk plot were $0.8 \mathrm{mM}$ and $3.3 \mathrm{mM}$ for ADP and phosphocreatine, respectively; $K_{m}$ values for the mitochondrial CK were $0.08 \mathrm{mM}$ and $2.5 \mathrm{mM}$ for ADP and phosphocreatine, respectively. Values of the inhibition constant $\left(K_{i}\right)$ for cytosolic CK inhibition by cystine, calculated from the Dixon plot (not shown), were 0.5 $\mathrm{mM}$ and $0.2 \mathrm{mM}$ for ADP and phosphocreatine, respectively; $K_{i}$ values for the mitochondrial CK were $0.3 \mathrm{mM}$ and $0.2 \mathrm{mM}$ for $\mathrm{ADP}$ and phosphocreatine, respectively. Since $K_{i}$ is the equilibrium constant for cystine binding and cystine concentration in kidney of patients with cystinosis is higher than $5 \mathrm{nmol} / \mathrm{mg}$ wet tissue (approximately $6 \mathrm{mM}$ ) (25), the CK isoforms would be strongly inhibited in case cystine is released from lysosomes. 
Table 2. In vitro effect of reduced GSH added before (pre) or after (post) preincubation with cystine for different times on creatine kinase activity in the kidney from young rats in the presence or absence cystine (Cys)

\begin{tabular}{|c|c|c|c|c|c|c|}
\hline Cellular fraction & \multicolumn{3}{|c|}{ Mitochondrial } & \multicolumn{3}{|c|}{ Cytosolic } \\
\hline Control (Cys $0 \mathrm{mM}$ ) & $74 \pm 11$ & $88 \pm 11$ & $107 \pm 11$ & $110 \pm 5$ & $100 \pm 16$ & $105 \pm 14$ \\
\hline GSH $1 \mathrm{mM}$ pre & $77 \pm 13$ & $101 \pm 11$ & $107 \pm 11$ & $114 \pm 12$ & $110 \pm 10$ & $115 \pm 11$ \\
\hline GSH $1 \mathrm{mM}$ post & - & $94 \pm 15$ & $100 \pm 15$ & - & $105 \pm 18$ & $111 \pm 18$ \\
\hline Cys $0.5 \mathrm{mM}+\mathrm{GSH} 1 \mathrm{mM}$ post & - & $53 \pm 10 \mathrm{a} \dagger$ & $82 \pm 10 \mathrm{a} \dagger$ & - & $60 \pm 11 \mathrm{a} \dagger, \mathrm{b} \dagger$ & $66 \pm 11 \mathrm{a} \dagger, \mathrm{b} \dagger$ \\
\hline
\end{tabular}

Creatine kinase activity is expressed as nmol creatine per minute per mg protein.

Data are means $\pm \mathrm{SD}$ for $n=6-8$ independent experiments performed in triplicate.

$* p<0.05, \dagger p<0.01$ for: $\mathrm{a}=$ different from the other groups; $\mathrm{b}=$ different from Cys $0.5 \mathrm{mM}$ (Tukey test).

Table 3. In vitro effect of cysteamine (CSH) added before (pre) or after (post) preincubation with cystine for different times on creatine kinase activity in the kidney from young rats in the presence or absence of $0.5 \mathrm{mM}$ cystine (Cys)

\begin{tabular}{|c|c|c|c|c|c|c|}
\hline \multirow[t]{2}{*}{ Cellular fraction } & \multicolumn{3}{|c|}{ Mitochondrial } & \multicolumn{3}{|c|}{ Cytosolic } \\
\hline & \multicolumn{3}{|c|}{ Preincubation time (min) } & \multicolumn{3}{|c|}{ Preincubation time (min) } \\
\hline Group & 0 & 30 & 60 & 0 & 30 & 60 \\
\hline Control (Cys $0 \mathrm{mM})$ & $66 \pm 8$ & $74 \pm 8$ & $98 \pm 11$ & $123 \pm 9$ & $105 \pm 8$ & $116 \pm 8$ \\
\hline $\mathrm{CSH} 2 \mathrm{mM}$ pre & $74 \pm 14$ & $84 \pm 7$ & $105 \pm 8$ & $117 \pm 12$ & $108 \pm 5$ & $110 \pm 9$ \\
\hline CSH $2 \mathrm{mM}$ post & - & $75 \pm 13$ & $100 \pm 15$ & - & $111 \pm 7$ & $109 \pm 9$ \\
\hline Cys $0.5 \mathrm{mM}$ & $51 \pm 6 a^{*}$ & $39 \pm 5 a \dagger$ & $70 \pm 10 a^{*}$ & $99 \pm 10 b^{*}$ & $33 \pm 2 \mathrm{a} \dagger$ & $44 \pm 4 \mathrm{a} \dagger$ \\
\hline Cys $0.5 \mathrm{mM}+\mathrm{CSH} 2 \mathrm{mM}$ pre & $80 \pm 14$ & $84 \pm 10$ & $104 \pm 10$ & $111 \pm 13 b^{*}$ & $90 \pm 4$ & $85 \pm 4 b^{*}$ \\
\hline Cys $0.5 \mathrm{mM}+\mathrm{CSH} 2 \mathrm{mM}$ post & - & $59 \pm 9 a^{*}$ & $100 \pm 15$ & - & $79 \pm 8 \mathrm{~b} \dagger$ & $73 \pm 8 \mathrm{~b} \dagger$ \\
\hline
\end{tabular}

Creatine kinase activity is expressed as nmol creatine per minute per mg protein.

Data are means \pm SD for $n=6-8$ independent experiments performed in triplicate.

$* p<0.05, \dagger p<0.01$ for: $\mathrm{a}=$ different from the other groups, $\mathrm{b}=$ different from the control (Tukey test).

\section{DISCUSSION}

We first investigated the in vivo effects of cystine, cysteamine, and cystine plus cysteamine on CK activity from kidney of young rats. The results showed that cystine administration reduced CK activity and co-administration of cysteamine prevented this inhibition. Furthermore, addition of GSH to the CK assay reversed the inhibition caused by cystine on CK activity, suggesting oxidation of critical thiol groups of the enzyme.

The in vitro experiments showed that cystine inhibited CK activity at different concentrations and times of preincubation. We then investigated the effects of GSH or CSH on the inhibition caused by cystine to clarify the underlying mechanisms of this inhibition. We observed that the inhibitory effect of cystine on CK was both prevented and reversed by cysteamine, suggesting that this inhibition was probably mediated by modification of important sulfhydryl groups of the enzyme. Competition studies between cystine and ADP or phosphocreatine showed a noncompetitive pattern. The $K_{i}$ values for cystine inhibition were at least 10-fold lower than cystine concentration found in the kidney of patients with cystinosis indicating that our results may be of pathophysiological significance (20).

Although tissue damage might depend on cystine accumulation, the mechanisms of cystine toxicity are still under investigation. Cystine is usually found inside the lysosomes. Mice lacking cystinosin accumulate cystine in the lysosomes but do not develop Fanconi syndrome (21), indicating that intralysosomal cystine accumulation per se may not cause tissue damage. Furthermore, histological studies in patients affected by cystinosis have shown a large accumulation of cystine in lysosomes of normally functioning cells, suggesting that cystine needs to be released from lysosomes to cause damage. There are several possibilities to explain how cystine could leave lysosomes and act into other cell compartments. It is possible that the small cystine crystals may partially disrupt the lysosomal membranes, because positive reactions for acid phosphatase, a lysosomal marker, were not always found in the periphery of the cystine crystals (22). Another possibility is the egress of cystine from lysosomes by secretion (23), followed by cystine transport back into the cytosol. In this context, it has been shown that cystine accumulates in the cytoplasm, nucleus, and cytoplasmic inclusions of dark cells, as well as extracellularly in the liver and in the kidney of patients with cystinosis, and in biopsies of renal allografts from patients with cystinosis, indicating that cystine crystals may not be limited to lysosomes (24). Inasmuch as the presence of dark cells is indicative of the early stages of autophagy (25), a form of cell death, it is conceivable that a great liberation of cystine into the cytosol caused by lysosomal membrane rupture or by cystine secretion and back transport could rapidly kill the cell. However, since cystine is nearly insoluble at $\mathrm{pH}$ ranging from 6 to 8, a rapid release of large amounts of cystine from its crystals killing cells is unlikely. 
Therefore, a slow dissolution of the cystine crystals may continuously liberate free cystine, leading to a sustained inhibition of thiol-containing enzymes and promoting cell death. On the other hand, is has been demonstrated a small and transient decrease of the glutathione pool in cystinotic cell lines during exponential growth phase (26), increasing four times the GSSG/GSH ratio (27). Considering that GSH slowly reacts with cystine to generate cysteine (28), it is possible that the increased free cystine concentration may explain the low GSH levels found in these cells. Furthermore, it is known that GSH depletion induces the mitochondrial permeability transition (MPT) causing cell death by apoptosis (29). Lysosomes are involved in apoptosis (30), and recent experiments with fibroblasts from cystinotic patients have shown that these cells are more prone to apoptosis (31). These investigators suggested that cystine accumulated in lysosomes can be released during the early permeabilization phase causing apoptosis mediated by a caspase-dependent cell death. Similarly, apoptosis was also induced by cystine in cultured human retinal pigment epithelial cells (32). It is also possible that cystine released induces a necrotic-like cell death via a caspaseindependent cell death (33). Moreover, it seems that the degree of ATP deprivation determines whether the cell death will occur by autophagy, apoptosis, or necrosis (34). In this scenario, energy deficit was observed in renal tubule cells loaded with cystine dimethyl ester, corresponding to a model of cystinosis with Fanconi syndrome (35). Moreover, addition of creatine to the diet of mice fully suppress the apoptosis induced by tumor necrosis factor- $\alpha$ (36), suggesting that apoptosis may be prevented by increasing energy metabolism.

Deficient activities of several thiol-containing enzymes, but not of nonthiol enzymes, were reported in postmortem liver and kidney tissues from patients with nephropathic cystinosis, but $\mathrm{CK}$ activity was not measured (20). It cannot be discarded that these enzymes may have normal activities in the intact cells and be inhibited by cystine released from the lysosomes after cell lysis (37).

Mi-CK is part of a unique temporal and spatial energy buffer system in tissues with high energy requirements, being also important to inhibit the $\mathrm{Ca}^{+2}$-induced opening of the mitochondrial permeability transition pore, which leads to apoptosis (38). It is well known that CK activity decreases after exposure to agents promoting generation of free radicals probably by oxidation of the sulfhydryl residues of the enzyme (39). This may explain our results showing that GSH prevented the inhibitory effect of cystine on CK activity.

We have already demonstrated that cystine inhibits in vitro CK activity in rat brain (13). In the present study, we demonstrate that cystine strongly inhibits in vivo and in vitro kidney CK activity and that cysteamine can prevent this inhibition. Considering that CK is a key enzyme for energy metabolism in renal cortex and outer medulla, in case cystine is released from lysosomes, these effects could also occur in the renal tubules of patients with cystinosis. Besides, other thiol-containing enzymes could be inhibited by a similar mechanism. In this case, it is possible to envisage that a diminution of these enzyme activities may potentially impair energy metabolism, contributing to the tissue damage through programmed cell death. This hypothesis is reinforced by other genetic (tyrosinemia, galactosemia, cytochrome $c$ oxidase deficiency) and acquired (heavy metals, drugs, maleate) causes of Fanconi Syndrome, in which the accumulated toxic substances cause energy deficit (40). Considering that cysteamine is used to treat patients with cystinosis because it causes parenchymal organ cystine depletion (4), the present data provides another possible beneficial effect for the use of this drug since the protective effect of cysteamine could be important in preventing some metabolic consequences of cystine accumulation, such as inhibition of CK activity. Further studies are however necessary to evaluate the activity of CK in patients affected by cystinosis.

\section{REFERENCES}

1. Gahl WA, Thoene JG, Schneider JA 2001 Cystinosis: a disorder of lysosomal membrane transport. In: Scriver CR, Beaudet AL, Sly WS, Valle D (eds) The Metabolic and Molecular Bases of Inherited Diseases, 8th Ed. McGraw-Hill, New York, pp 5085-5108

2. Town M, Jean G, Cherqui S, Attard M, Forestier L, Whitmore SA, Callen DF, Gribouval O, Broyer M, Bates GP, van't Hoff W, Antignac C 1998 A novel gene encoding an integral membrane protein is mutated in nephropathic cystinosis. Nat Genet 18:319-324

3. Schneider JA, Clark KF, Greene AA, Reisch JS, Markello TC, Gahl WA, Thoene JG, Noonan PK, Berry KA 1995 Recent advances in the treatment of cystinosis. J Inherit Metab Dis 18:387-397

4. Gahl WA, Charnas L, Markello TC, Bernardini I, Ishak KG, Dalakas MC 1992 Parenchymal organ cystine depletion with long-term cysteamine therapy. Biochem Med Metab Biol 48:275-285

5. Baum M 1998 The Fanconi syndrome of cystinosis: insights into the pathophysiology. Pediatr Nephrol 12:492-497

6. Mahoney CP, Striker GE 2000 Early development of the renal lesions in infantile cystinosis. Pediatr Nephrol 15:50-56

7. Laube GF, Haq MR, van't Hoff WG 2005 Exfoliated human proximal tubular cells: a model of cystinosis and Fanconi syndrome. Pediatr Nephrol 20:136-140

8. Gilbert HF 1984 Redox control of enzyme activities by thiol/disulfide exchange. Methods Enzymol 107:330-351

9. Wallimann T, Wyss M, Brdiczka D, Nicolay K, Eppenberger HM 1992 Intracellular compartmentation, structure and function of creatine kinase isoenzymes in tissues with high and fluctuating energy demands: the 'phosphocreatine circuit' for cellular energy homeostasis. Biochem J 281:21-40

10. Friedman DL, Perryman MB 1991 Compartmentation of multiple forms of creatine kinase in the distal nephron of the rat kidney. J Biol Chem 266:22404-22410

11. Cetinkaya I, Schlatter E, Hirsch JR, Herter P, Harms E, Kleta R 2002 Inhibition of $\mathrm{Na}+$-dependent transporters in cystine-loaded human renal cells: electrophysiological studies on the Fanconi syndrome of cystinosis. J Am Soc Nephrol 13:2085-2093

12. Assuncao Guimaraes C, Linden R 2004 Programmed cell death. Apoptosis and alternative deathstyles. Eur J Biochem 271:1638-1650

13. Fleck RM, Rodrigues V Jr, Giacomazzi J, Parissoto D, Dutra-Filho CS, Wyse AT, Wajner M, Wannmacher CM 2005 Cysteamine prevents and reverses the inhibition of creatine kinase activity caused by cystine in rat brain cortex. Neurochem Int 46:391-397

14. Lowry OH, Rosebrough NJ, Farr AL, Randall RJ 1951 Protein measurement with the folin phenol reagent. J Biol Chem 193:265-275

15. Sullivan MX, Hess WC, Howard HW 1942 The quantitative estimation of both cystine and cystein in mixture. J Biol Chem 145:621-624

16. Hughes BP 1962 A method for the estimation of serum creatine kinase and its use in comparing creatine kinase and aldolase activity in normal and pathological sera. Clin Chim Acta 7:597-603

17. Lash LH 2005 Role of glutathione transport processes in kidney function. Toxicol Appl Pharmacol 204:329-342

18. Lineweaver H, Burk D 1934 The determination of enzyme dissociation constants. J Am Chem Soc 56:658-666

19. Dixon M, Webb EC 1964 Enzyme Kinetics, 2nd Ed. Longman, London

20. Patrick AD 1965 Deficiencies of SH-dependent enzymes in cystinosis. Clin Sci 28:427-443

21. Cherqui S, Sevin C, Hamard G, Kalatzis V, Sich M, Pequignot MO, Gogat K, Abitbol M, Broyer M, Gubler MC, Antignac C 2002 Intralysosomal cystine accumulation in mice lacking cystinosin, the protein defective in cystinosis. Mol Cell Biol 22:7622-7632

22. Koizumi F, Koeda T, Wakaki K, Matumoto M, Kobashi K, Akao T, Fukase M 1985 Cystinosis with marked atrophy of the kidneys and thyroid. Histological and ultrastructural studies in an autopsy case. Acta Pathol Jpn 35:145-155

23. Andrews NW 2000 Regulated secretion of conventional lysosomes. Trends Cell Biol 10:316-321

24. Spear GS, Gubler MC, Habib R, Broyer M 1989 Dark cells of cystinosis: occurrence in renal allografts. Human Pathol 20:472-476 
25. Clarke PG 1990 Developmental cell death: morphological diversity and multiple mechanisms. Anat Embryol (Berl) 181:195-213

26. Chol M, Nevo N, Cherqui S, Antignac C, Rustin P 2004 Glutathione precursors replenish decreased glutathione pool in cystinotic cell lines. Biochem Biophys Res Commun 324:231-235

27. Wilmer MJ, de Graaf-Hess A, Blom HJ, Dijkman HB, Monnens LA, van den Heuvel LP, Levtchenko EN 2005 Elevated oxidized glutathione in cystinotic proximal tubular epithelial cells. Biochem Biophys Res Commun 337:610-614

28. Jones DP, Go YM, Anderson CL, Ziegler TR, Kinkade JM Jr, Kirlin WA 2004 Cysteine/cystine couple is a newly recognized node in the circuitry for biologic redox signaling and control. FASEB J 18:1246-1248

29. Armstrong JS, Jones DP 2002 Glutathione depletion enforces the mitochondrial permeability transition and causes cell death in Bcl-2 overexpressing HL60 cells. FASEB J 16:1263-1265

30. Stoka V, Turk B, Schendel SL, Kim TH, Cirman T, Snipas SJ, Ellerby LM, Bredesen D, Freeze H, Abrahamson M, Bromme D, Krajewski S, Reed JC, Yin XM, Turk V, Salvesen GS 2001 Lysosomal protease pathways to apoptosis. Cleavage of bid, not pro-caspases, is the most likely route. J Biol Chem 276:3149-3157

31. Park MA, Thoene JG 2005 Potential role of apoptosis in development of the cystinotic phenotype. Pediatr Nephrol 20:441-446

32. Jiang S, Moriarty-Craige SE, Orr M, Cai J, Sternberg P Jr, Jones DP 2005 Oxidant-induced apoptosis in human retinal pigment epithelial cells: dependence on extracellular redox state. Invest Ophthalmol Vis Sci 46:1054-1061
33. Kitanaka C, Kuchino Y 1999 Caspase-independent programmed cell death with necrotic morphology. Cell Death Differ 6:508-515

34. Burlacu A, Jinga V, Gafencu AV, Simionescu M 2001 Severity of oxidative stress generates different mechanisms of endothelial cell death. Cell Tissue Res 306:409416

35. Ben-Nun A, Bashan N, Potashnik R, Cohen-Luria R, Moran A 1993 A cystine loading induces Fanconi's syndrome in rats: in vivo and vesicle studies. Am J Physiol 265:F839-F844

36. Hatano E, Tanaka A, Kanazawa A, Tsuyuki S, Tsunekawa S, Iwata S, Takahashi R, Chance B, Yamaoka Y 2004 Inhibition of tumor necrosis factor-induced apoptosis in transgenic mouse liver expressing creatine kinase. Liver Int 24:384-393

37. Schneider JA, Schulman JD 1983 Cystinosis. In: Stanbury JB, Wyngaarden JB, Fredrickson DS, Goldstein JL, Brown MS (eds) The Metabolic Basis of Inherited Disease, 5th Ed. McGraw-Hill, New York, pp 1844-1866

38. O'Gorman E, Beutner G, Dolder M, Korestsky AP, Brdiczka D, Wallimann T 1997 The role of creatine kinase in inhibition of mitochondrial permeability transition. FEBS Lett 414:253-257

39. Koufen P, Stark G 2000 Free radical induced inactivation of creatine kinase: sites of interaction, protection, and recovery. Biochim Biophys Acta 1501:44-50

40. Bergeron M, Gougoux A, Noël J, Parent L 2001 The renal Fanconi syndrome. In: Scriver CR, Beaudet AL, Sly WS, Valle D (eds) The Metabolic and Molecular Bases of Inherited Diseases, 8th Ed. McGraw-Hill, New York, pp 5023-5038 